\title{
Molecular Phylogenetic Analyses of Biological Control Strains of Trichoderma harzianum and Other Biotypes of Trichoderma spp. Associated with Mushroom Green Mold
}

\author{
M. D. Ospina-Giraldo, D. J. Royse, X. Chen, and C. P. Romaine
}

Department of Plant Pathology, The Pennsylvania State University, University Park 16802.

Accepted for publication 29 December 1998.

\begin{abstract}
Ospina-Giraldo, M. D., Royse, D. J., Chen, X., and Romaine, C. P. 1999. Molecular phylogenetic analyses of biological control strains of Trichoderma harzianum and other biotypes of Trichoderma spp. associated with mushroom green mold. Phytopathology 89:308-313.

A polymerase chain reaction-amplified DNA containing the internal transcribed spacer (ITS)-1, 5.8S, and ITS-2 regions of the nuclear ribosomal DNA transcriptional unit was sequenced for 81 isolates of Trichoderma spp. associated with mushroom culture or used for biological control of plant pathogens. Phylogenetic analyses revealed that the biocontrol

demics that have occurred during the last 12 years in Europe and North America. Three isolates of T. harzianum obtained from shiitake (Lentinula edodes; Shi1B and S3-96) and maitake (Grifola frondosa; Mai1) substrates were placed within the biocontrol group. We also found evidence suggesting that some isolates of T. harzianum originally identified as Th4 from Pennsylvania are more closely related to Th2 from Europe. Finally, considering the wide range in sequence distribution of our samples, we propose that the consensus sequence found in this investigation be used as the reference sequence for further studies involving the identification and taxonomy of T. harzianum.
\end{abstract} isolates were more closely related to an isolate of T. harzianum biotype 1 (Th1) than to the aggressive biotypes 2 and 4 . Th1 has been isolated from mushroom compost but is not the cause of widespread green mold epi-
Additional keywords: Agaricus bisporus, ITS sequences, systematics.
Trichoderma harzianum is the cause of green mold, a disorder that affects the common cultivated mushroom Agaricus bisporus. The disease is characterized by a rapid infestation of the compost by $T$. harzianum and subsequent inhibition of A. bisporus fructification. Although green mold has been associated with $A$. bisporus since it was first cultivated over 300 years ago, the malady caused only minor crop losses for growers. During the last 12 years, however, new, aggressive forms of the pathogen have led to severe crop losses in the British Isles (7,17,18,27-31). In the early 1990s, growers in Ontario (23), British Columbia (23), and Pennsylvania (24) experienced outbreaks of green mold similar to those in the British Isles. Since then, losses are estimated to have exceeded $\$ 30$ million dollars in North America alone.

Four biotypes of $T$. harzianum, designated Th1, Th2, Th3, and Th4, have been found associated with mushroom compost. Biotype Th3, previously identified as $T$. harzianum, recently was recognized as a strain of $T$. atroviride $(5,20)$. Biotypes Th2 and Th4 are the most aggressive, causing the majority of crop losses. In Pennsylvania, the predominant biotype associated with the green mold epidemic is Th4, as shown by random amplified polymorphic DNA (RAPD) analysis (21). Biotype Th4 also is the major cause of crop loss in Canada (23).

Several species of Trichoderma are well-documented mycoparasites and have been used successfully against certain pathogenic fungi $(6,34)$. Among these, T. harzianum is the species most often used for biological control of pathogens. It is commercially available as F-Stop (Eastman Kodak Co., Rochester, NY) for control of several soilborne plant-pathogenic fungi and, in combination with $T$. polysporum (as BINAB T; Binab USA, Inc., Bridgeport, CT), for control of wood decay (1). The genetic relationship

Corresponding author: D. J. Royse; E-mail address: djr4@psu.edu

Publication no. P-1999-0201-01R

(C) 1999 The American Phytopathological Society among these strains and biotypes Th2 and Th4 has not been examined. Concern has emerged regarding the potential role of biological control strains in the development of mushroom green mold epidemics. Phylogenetic analyses would help clarify these relationships and may provide useful information about strategies to control the disease.

We compared nucleotide sequences from the ribosomal DNA transcriptional unit (rDNA) of 81 isolates, comprising green moldand biocontrol-related isolates of $T$. harzianum and other species of Trichoderma. We found that, although the isolates known for biological control properties and green mold-associated isolates share a recent ancestor, they constitute different phylogenetic groups.

\section{MATERIALS AND METHODS}

Cultures. A total of 81 isolates of Trichoderma spp., representing T. harzianum Th4 as well as other green mold-associated biotypes, were used in this study. These isolates constitute a wide, geographically distributed sample. All biological control strains of Trichoderma spp. available in the American Type Culture Collection (ATCC) were included in this analysis (Table 1).

DNA extraction. Fungal genomic DNA was extracted using the Puregene kit (Gentra Systems, Inc., Minneapolis, MN), following the manufacturer's directions. Fungal tissue, ground in liquid nitrogen, was lysed with the cell lysis solution provided. After incubation at $55^{\circ} \mathrm{C}$, an RNase treatment was performed, followed by protein extraction. DNA was precipitated with isopropanol, washed with ethanol (70\%), and air-dried for 15 min. DNA was rehydrated with $50 \mu \mathrm{l}$ of DNA hydration solution (10 mM Tris and $1 \mathrm{mM}$ EDTA).

Polymerase chain reaction (PCR) amplification of internal transcribed spacer (ITS)-1 and -2 regions and 5.8S rDNA. DNA (10 ng) was amplified in 15- $\mu \mathrm{l}$ PCR mixtures containing $0.4 \mathrm{U}$ of Taq DNA polymerase (Promega Corp., Madison, WI), $0.2 \mathrm{mM}$ each dNTP, $0.5 \mu \mathrm{M}$ primers ITS-1 (5' TCTGTAGGTGAACCTGCGG 3') (26) and ALR0 (5' CATATGCTTAAGTTCAGCGGG 3'), 
and $2 \mathrm{mM} \mathrm{MgCl}$. Reactions were performed in capillary tubes using a Rapidcycler (Idaho Technology, Idaho Falls, ID) with the following program: 1 cycle at $94^{\circ} \mathrm{C}$ for $15 \mathrm{~s} ; 40$ cycles at $94^{\circ} \mathrm{C}$ for $0 \mathrm{~s}, 56^{\circ} \mathrm{C}$ for $15 \mathrm{~s}$, and $72^{\circ} \mathrm{C}$ for $45 \mathrm{~s}$; and 1 cycle at $72^{\circ} \mathrm{C}$ for $2 \mathrm{~min}$.

Sequencing of PCR products. PCR products from eight $15-\mu \mathrm{l}$ reactions of each sample were purified with the Wizard PCR system (Promega Corp.), and the concentration was adjusted to $20 \mathrm{ng} / \mu \mathrm{l}$. DNA sequences were obtained by automated DNA sequencing with fluorescent terminators using an ABI 377 Prism Sequencer (Applied Biosystems, Inc., Foster City, CA) at the Nucleic Acid Facility, Biotechnology Institute, The Pennsylvania State University. Each sample was sequenced in both directions with the same primers that were used in the amplification step. Consensus sequences were determined using the Seqman module from the Lasergene software package (DNASTAR Inc., Madison, WI).

Data analysis. Sequences were aligned following the Clustal W algorithm (33) included in the Megalign module (DNASTAR Inc.). Multiple alignments parameters used were gap penalty $=10$ and gap length penalty $=10$. Both of these values are aimed to prevent lengthy or excessive numbers of gaps. The default parameters (Ktuple $=2$, gap penalty $=5$, window $=4$, and diagonals saved $=4$ ) were used for the pairwise alignment. The use of Clustal $\mathrm{W}$ determines that, once a gap is inserted, it can only be removed by editing. Therefore, final alignment adjustments were made manually in order to remove artificial gaps. Phylogenetic analyses were com- pleted using the MEGA package (version 1.01; Institute of Molecular Evolutionary Genetics, University Park, PA) (26). Neither gaps (due to insertion-deletion events) nor equivocal sites were considered phylogenetically informative. Hence, complete deletion prevented the use of any of these sites in further analyses. Nucleotide distances were estimated by the Jukes-Cantor model (12), and phylogenetic inference was performed by the neighborjoining (NJ) method (26). Bootstrap tests with 1,000 replications (8) were conducted to examine the reliability of the interior branches and the validity of the trees obtained. An additional standard error test was performed with the data set using the same characters in order to evaluate the statistical confidence of the inferred phylogeny.

\section{RESULTS}

Amplification of the rDNA region with primers ITS-1 and ALR0 yielded products of approximately $600 \mathrm{bp}$ as estimated by agarose gel electrophoresis. The sequences used for the final phylogenetic analysis were 532 to $548 \mathrm{bp}$ after manual contig trimming. In addition to ITS-1, 5.8S rDNA, and ITS-2, such sequences contained the last base of the 18S rDNA and the first 12 bases of the 28S rDNA.

Isolates of Trichoderma spp. used as biocontrol agents showed the highest nucleotide variation in the ITS-1 region (31.0\%), followed by the ITS-2 (14.0\%) and the 5.8S rDNA (11.3\%) regions, respectively (Table 2). Within ITS-1, most of the substitutions (38)

TABLE 1. List of species, isolate code, source, geographic origin, and GenBank accession number for Trichoderma spp. analyzed in this study

\begin{tabular}{|c|c|c|c|c|c|c|c|c|c|}
\hline Species & $\begin{array}{l}\text { Isolate } \\
\text { code }\end{array}$ & Source $^{\mathrm{a}}$ & $\begin{array}{c}\text { Geographic } \\
\text { origin }\end{array}$ & $\begin{array}{c}\text { GenBank } \\
\text { accession no. }\end{array}$ & Species & $\begin{array}{l}\text { Isolate } \\
\text { code }\end{array}$ & Source $^{\mathrm{a}}$ & $\begin{array}{c}\text { Geographic } \\
\text { origin }\end{array}$ & $\begin{array}{c}\text { GenBank } \\
\text { accession no. }\end{array}$ \\
\hline T. atroviride $\mathrm{b}^{\mathrm{b}, \mathrm{c}}$ & $N / A^{d}$ & ATCC 32173 & Israel & Z48811 & T. harzianum & Th4-85 & Romaine/Royse & Berks Co., PA & AF057620 \\
\hline T. atroviride ${ }^{\mathrm{b}}$ & 36042 & ATCC 36042 & N/A & Z48812 & T. harzianum & Th4-89 & Beyer/Royse & Berks Co., PA & AF057621 \\
\hline T. atroviride $\mathrm{e}^{\mathrm{b}, \mathrm{c}}$ & N/A & ATCC 42831 & Hungary & Z48811 & T. harzianum & Th4-90 & D. Rinker & Canada & AF057622 \\
\hline T. atroviride ${ }^{\mathrm{b}}$ & $95-41$ & ATCC 28036 & North Carolina & AF057604 & T. harzianum & Th4-91 & D. Rinker & Canada & AF057623 \\
\hline T. harzianum & $95-40$ & CBS 227-95 & N/A & AF057605 & T. harzianum & Th4-92 & D. Rinker & Canada & U78882 \\
\hline T. harzianum & $95-43$ & CBS 226-95 & N/A & AF057606 & T. harzianum & Th4-96 & D. Royse & Chester Co., PA & AF057624 \\
\hline T. harzianum & 20691 & ATCC 20691 & N/A & AF057571 & T. harzianum & Th4-105 & D. Beyer & Chester Co., PA & AF057625 \\
\hline T. harzianum & 20846 & ATCC 20846 & N/A & AF057572 & T. harzianum & Th4-108 & D. Beyer & Chester Co., PA & AF057626 \\
\hline T. harzianum & 20847 & ATCC 20847 & N/A & AF057573 & T. harzianum & Th4-109 & D. Beyer & Chester Co., PA & AF057627 \\
\hline T. harzianum & 20848 & ATCC 20848 & N/A & AF057574 & T. harzianum & Th4-111 & D. Beyer & Berks Co., PA & AF057628 \\
\hline T. harzianum & 20873 & ATCC 20873 & N/A & AF057575 & T. harzianum & Th4-112 & D. Beyer & Berks Co., PA & AF057629 \\
\hline T. harzianum & 20902 & ATCC 20902 & New York & AF057576 & T. harzianum & Th4-113 & D. Beyer & Berks Co., PA & AF057630 \\
\hline T. harzianum & 20907 & ATCC 20907 & New York & AF057577 & T. harzianum & Th4-114 & D. Beyer & Berks Co., PA & AF057631 \\
\hline T. harzianum & 52424 & ATCC 52424 & Ohio & AF057578 & T. harzianum & Th4-116 & D. Beyer & Berks Co., PA & AF057632 \\
\hline T. harzianum & 52443 & ATCC 52443 & Georgia & AF057579 & T. harzianum & Th4-117 & D. Beyer & Berks Co., PA & AF057633 \\
\hline T. harzianum & 52444 & ATCC 52444 & N/A & AF057580 & T. harzianum & Th4-118 & D. Beyer & Berks Co., PA & AF057634 \\
\hline T. harzianum & 52445 & ATCC 52445 & N/A & AF057581 & T. harzianum & Th4-119 & D. Beyer & Berks Co., PA & AF057635 \\
\hline T. harzianum & 56678 & ATCC 56678 & New York & AF057582 & T. harzianum & Th4-120 & D. Beyer & Berks Co., PA & AF057636 \\
\hline T. harzianum & 58673 & ATCC 58673 & Maryland & AF057583 & T. harzianum & Th4-121 & D. Beyer & Berks Co., PA & AF057637 \\
\hline T. harzianum & 58674 & ATCC 58674 & Maryland & AF057584 & T. harzianum & Th4-122 & D. Beyer & Chester Co., PA & AF057638 \\
\hline T. harzianum & 60850 & ATCC 60850 & Colombia & AF057585 & T. harzianum & Th4-123 & D. Beyer & Chester Co., PA & AF057639 \\
\hline T. harzianum & 64263 & ATCC 64263 & Hungary & AF057586 & T. harzianum & Th4-169 & C. P. Romaine & Chester Co., PA & AF057640 \\
\hline T. harzianum & Th1-64 & P. Mills & Northern Ireland & AF057599 & T. harzianum & Th4-170 & C. P. Romaine & Chester Co., PA & AF057641 \\
\hline T. harzianum & Th1-65 & P. Mills & Northern Ireland & U78881 & T. harzianum & Th4-171 & C. P. Romaine & Chester Co., PA & AF057642 \\
\hline T. harzianum & Th2-62 & P. Mills & Northern Ireland & AF057600 & T. harzianum & Th4-172 & C. P. Romaine & Chester Co., PA & AF057643 \\
\hline T. harzianum & Th2-63 & P. Mills & Northern Ireland & U78880 & T. harzianum & Th4-178 & D. Beyer & Chester Co., PA & AF057644 \\
\hline T. harzianum & Th3-60 & P. Mills & Northern Ireland & AF057601 & T. harzianum & A5-96 & D. J. Royse & Chester Co., PA & AF057587 \\
\hline T. harzianum & Th3-61 & P. Mills & Northern Ireland & U78879 & T. harzianum & A6-96 & D. J. Royse & Chester Co., PA & AF057588 \\
\hline T. harzianum & Th4-12 & G. J. Samuels & Berks Co., PA & U78877 & T. harzianum & A9-96 & D. J. Royse & Chester Co., PA & AF057589 \\
\hline T. harzianum & Th4-23 & D. J. Royse & Berks Co., PA & AF057609 & T. harzianum & Mai1 & D. J. Royse & Maitake, MRC & AF057590 \\
\hline T. harzianum & Th4-24 & D. J. Royse & Berks Co., PA & AF057610 & T. harzianum & Ple1 & D. J. Royse & Pleurotus, MRC & AF057591 \\
\hline T. harzianum & Th4-31 & C. Fordyce & N/A & AF057611 & T. harzianum & Shi1 & D. J. Royse & Shiitake, MRC & AF057595 \\
\hline T. harzianum & Th4-32 & C. Fordyce & N/A & AF057612 & T. harzianum & Shi2 & D. J. Royse & Shiitake, MRC & AF057596 \\
\hline T. harzianum & Th4-33 & C. Fordyce & N/A & AF057613 & T. harzianum & Shi3 & D. J. Royse & Shiitake, MRC & AF057597 \\
\hline T. harzianum & Th4-35 & C. P. Romaine & Chester Co., PA & AF057614 & T. harzianum & Shi4 & D. J. Royse & Shiitake, MRC & AF057598 \\
\hline T. harzianum & Th4-36 & D. J. Royse & MRC & U78878 & T. harzianum & S1-96 & D. J. Royse & Shiitake, Chester Co., PA & AF057592 \\
\hline T. harzianum & Th4-66 & D. J. Royse & Chester Co., PA & AF057615 & T. harzianum & S3-96 & D. J. Royse & Shiitake, Chester Co., PA & AF057593 \\
\hline T. harzianum & Th4-69 & D. Beyer & Berks Co., PA & AF057616 & T. harzianum & S5-96 & D. J. Royse & Shiitake, Chester Co., PA & AF057594 \\
\hline T. harzianum & Th4-72 & Romaine/Royse & Berks Co., PA & AF057617 & T. inhamatum & $95-39$ & G. J. Samuels & N/A & AF057602 \\
\hline T. harzianum & Th4-78 & Romaine/Royse & Berks Co., PA & AF057618 & T. virens & Tvir2 & Growth promoter & N/A & AF057603 \\
\hline T. harzianum & Th4-79 & Romaine/Royse & Berks Co., PA & AF057619 & & & & & \\
\hline
\end{tabular}

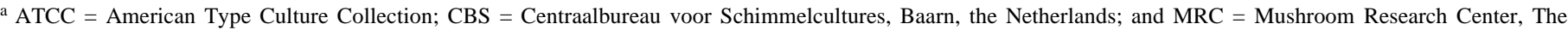
Pennsylvania State University.

b These strains appear in the ATCC catalogue under different names. New names determined by W. Gams (13).

${ }^{c}$ DNA sequences from these strains are identical and are reported in the GenBank with the same accession number.

${ }^{\mathrm{d}} \mathrm{N} / \mathrm{A}=$ not available. 
were located in a 87-nucleotide (nt) range between sites 112 and 198. No substitutions were found within the last 13 positions of ITS-1. Within ITS-2, more than half of the substitutions (13) were clustered in a 23 -nt range between sites 415 and 438 near the region's center. There were only two changes in the first 43 base positions of ITS-2. A similar trend was observed in the 5.8S rRNA gene, in which eight changes occurred in a central 26-nt segment but only three changes were found in the last 59 positions of the sequence (Fig. 1). Transitions accounted for most of the substitutions and the transition/transversion ratios were as high as 8.0.

DNA sequence analysis of biocontrol-related $T$. harzianum isolates only revealed that ITS-1 contained most of the nucleotide changes (Table 2). The substitution percentage in this region $(19.1 \%)$ is almost four times that of ITS-2 (5.8\%). With the sole exception of the absence of base changes in the last 15 positions, no major trend was observed in the substitution pattern in ITS-1. In the case of ITS-2, only two base changes were found in the first 44 positions of the region. Likewise, only two substitutions occurred within the last 73 nt of ITS-2. Six additional changes were observed in a 55-nt segment spanning positions 417 through 471 of the sequence alignment. For the 5.8S rDNA, the substitution pattern was very similar to the one described above, with most changes observed toward the middle of the gene. The transition/transversion ratio ranged from 0.33 to 5.0 .

For Th4 isolates, the ITS-1 region showed the highest percentage of nucleotide substitutions (20.6\%) (Table 2). For the 5.8S rDNA, 20 changes $(12.6 \%)$ were found, 14 of them in the first 50 positions of the gene and only 6 in the last 109 nt sites. The ITS- 2 region had a percentage of substitutions $(12.9 \%)$ similar to that of the 5.8S rRNA gene, but none were observed within the first 48 bases.

Sequence comparison among all isolates used in this study revealed that most of the nucleotide variation occurred in ITS-1 (Table 2). Within this region, a significant number of substitutions were found near the $3^{\prime}$ end. The remaining substitutions were spread evenly throughout the rest of ITS-1. Out of 160 sites evaluated in the 5.8S rDNA, 29 were different from the consensus sequence.
Differences were mainly located in the first $65 \mathrm{nt}$ of the gene, with only 11 differences found in the last 95 positions of the $5.8 \mathrm{~S}$ rDNA. ITS-2 accounted for $10 \%$ of the total variation among all fungal sequences examined. Only three substitutions were found in the first $37 \mathrm{nt}$ of the ITS-2 sequence.

The phylogenetic tree of all isolates (Fig. 2) revealed the presence of multiple clusters. One cluster contained T. atroviride (Th3 isolates) and the biocontrol strain ATCC 64263. This cluster shares the oldest ancestor of the isolates studied. At least six other subgroups are derived from this ancestor. Isolates obtained from shiitake substrate and A. bisporus compost clustered together and share the most recent ancestor with an isolate of Th1. A specimen of $T$. virens, isolated from a commercial growth promoter, is closely related to this cluster. Biocontrol- and green mold-related strains that share a very recent common ancestor formed two other subgroups. This distinction, however, was not very well supported by bootstrap tests. The biocontrol subgroup included 16 isolates (out of the 17 used in this study) of T. harzianum and 1 isolate of T. inhamatum, known for their antagonistic properties. However, this subgroup also included one specimen of Th1 and several samples obtained from green mold-infested shiitake, maitake, and $A$. bisporus substrates. The sister subgroup, constituted by the aggressive Th4 isolates, contained further subdivisions. Isolates 120, 122, 123, and 169 of Th4 are part of an independent lineage. The other subdivision contained the remaining confirmed Th4 isolates and one additional sample from Pleurotus ostreatus and A. bisporus substrates, respectively.

\section{DISCUSSION}

The genus Trichoderma poses a major challenge for systematists because the phylogenetic relationships of many of its members still are unclear (11). The concepts of "species aggregate" and "section" introduced by Rifai (22) and Bissett (2) have helped clarify placement of conflictive species such as T. harzianum, $T$. viride, and T. atroviride within the genus. However, the influence

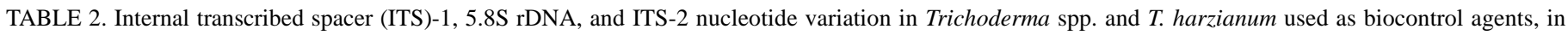
Th4 biotype isolates associated with mushroom culture, and in all isolates used in this study ${ }^{\mathrm{a}}$

\begin{tabular}{|c|c|c|c|c|c|c|c|c|c|c|}
\hline \multirow[b]{2}{*}{ Specimen } & \multirow[b]{2}{*}{ Sequences $^{\mathrm{b}}$} & \multicolumn{3}{|c|}{ ITS-1 } & \multicolumn{3}{|c|}{$5.8 \mathrm{~S}$ rDNA } & \multicolumn{3}{|c|}{ ITS-2 } \\
\hline & & Sites $^{\mathrm{c}}$ & Total $^{\mathrm{d}}$ & $\mathrm{V}(\%)^{\mathrm{e}}$ & Sites & Total & $\mathrm{V}(\%)$ & Sites & Total & $\mathrm{V}(\%)$ \\
\hline Trichoderma spp. ${ }^{\mathrm{f}}$ & 21 & 65 & 210 & 31.0 & 18 & 160 & 11.3 & 25 & 179 & 14.0 \\
\hline T. harzianum & 17 & 40 & 210 & 19.1 & 15 & 160 & 9.4 & 10 & 173 & 5.8 \\
\hline Th4 biotype ${ }^{g}$ & 39 & 42 & 204 & 20.6 & 20 & 159 & 12.6 & 23 & 179 & 12.9 \\
\hline All isolates ${ }^{\mathrm{h}}$ & 80 & 92 & 215 & 42.8 & 29 & 160 & 18.1 & 56 & 185 & 30.3 \\
\hline
\end{tabular}

a Gaps and equivocal sites were removed from the data set before analysis.

b Number of sequences.

c Number of different sites.

d Total number of sites compared.

e $\mathrm{V}=$ sequence variation.

f Species included are T. atroviride, T. harzianum, T. inhamatum, and T. virens.

$\mathrm{g}$ Th4 = T. harzianum biotype 4 from Pennsylvania and Canada.

h Two strains of T. atroviride, ATCC 32173 and ATCC 42831, have identical DNA sequence and share the same GenBank accession number.

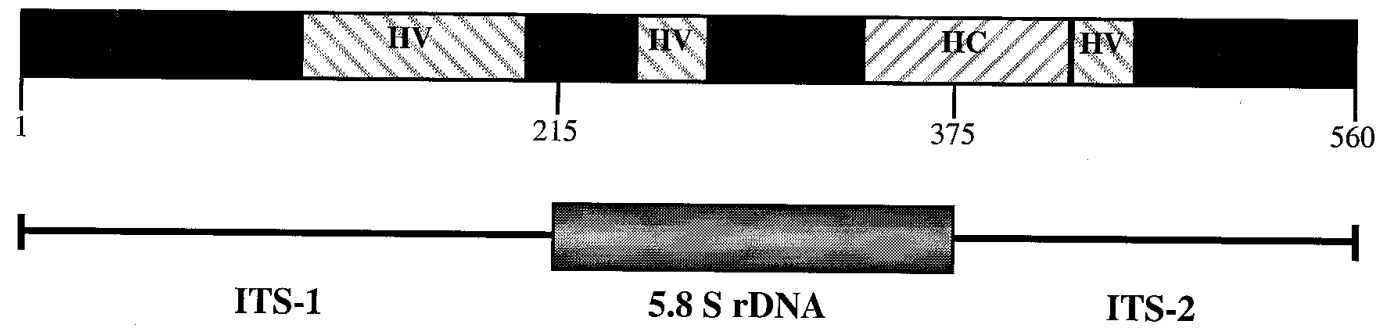

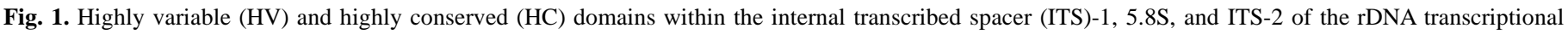
unit of biocontrol species of Trichoderma. A similar pattern was observed for all isolates of Trichoderma spp. examined in this study. Scale: bar $=100$ bp. 
of environmental conditions on morphological and physiological characteristics have made accurate identification of new biotypes difficult (16). Such is the case with some green mold-associated isolates, in which initial identifications classified them as members of $T$. harzianum. For example, molecular phylogenetic analysis has demonstrated that Th3 is $T$. atroviride rather than $T$. harzianum $(5,20)$.

rRNA genes from closely related species are highly evolutionarily conserved and share significant sequence similarity (4). Their slower evolutionary rate increases the usefulness of these genes for phylogenetic studies of distantly related organisms (35). In contrast, ITS and intergenic region domains are much more variable and, therefore, more useful for phylogenetic studies of members of the same species or genus (35). In this study, however, comparisons involving biocontrol- or green mold-related isolates of $T$. harzianum only revealed that the 5.8S rRNA gene is as variable as, or even more so than, ITS-2. For example, green mold isolates show almost equal rates of substitutions (12.6 versus $12.9 \%$ for the $5.8 \mathrm{~S}$ rDNA and ITS-2, respectively). Furthermore, in T. harzianum biocontrol isolates, the 5.8S rRNA gene is more variable than ITS-2 (9.4 and $5.8 \%$, respectively). This result appears to be the consequence of a substantially lower degree of variation within ITS-2 for these isolates.

The sequence alignment using Clustal $\mathrm{W}$ revealed that, in all cases, the ITS-1 region accounted for the highest amount of nucleotide variation. A segment encompassing approximately $50 \mathrm{nu}-$ cleotides near the $3^{\prime}$ end contained the highest number of substitutions when compared with other segments of similar length. These results suggest the presence of a "hot spot" within ITS-1, where substitutions occur more frequently. In addition, very few changes were found in the last 15 bases of ITS-1. This region fuses with the $5^{\prime}$ end of the 5.8S rRNA gene, also a domain with relatively little variation. The most conserved segment of the rDNA region examined is located between the last 35 bases of the 5.8S rDNA and the first 35 to 45 sites of ITS-2, where virtually no variation occurs. Such conservation could be related to the necessity of a conserved sequence for ribonuclease recognition during further processing of the heterogeneous rRNA transcript. However, since only partial information is known regarding the processing of the rRNA primary transcript in eukaryotes (14), it is difficult to determine the biological significance of this finding.

Phylogenetic analysis indicates that green mold-causing biotypes and biocontrol isolates are very closely related and share the most recent common ancestor (Fig. 2). Bootstrap analysis, using 1,000 replications, of the $\mathrm{NJ}$ tree provides weak evidence to place both groups in distinct clades. However, no biocontrol strain was ever placed as the most recent ancestor of an aggressive biotype. Alternative tree topologies, using different bootstrap cutoff values, also appear to support such a hypothesis (data not shown). A nonaggressive isolate of the Th1 biotype was almost identical in sequence to biocontrol strain ATCC 20873. This strain was reportedly obtained by protoplast fusion of ATCC 20737 and ATCC 60850. In addition, three other green mold-associated isolates (Mai1, Shi1B, and S3-96), found on substrates of the specialty mushrooms shiitake and maitake, were placed within the biocontrol group. The standard error analysis, a statistically robust test in which the null hypothesis of branch-length-equal-to-zero is tested, also supported the results obtained after bootstrapping (data not shown).

Fig. 2. Phylogenetic relationships of 81 isolates of Trichoderma spp. inferred from rDNA sequence analysis. The phylogenetic tree was obtained by the neighbor-joining method using the Jukes-Cantor distance. The number of nucleotides in the subset was 572. Gaps and equivocal sites were excluded from the analysis. The numbers above the branches represent the values obtained after a bootstrap test with 1,000 replications. GenBank accession no. Z48811 represents ATCC 32173 and ATCC 42831 strains of T. atroviride. Clusters within Th4 and Th2/Th4 subgroups are labeled A and B, respectively.
Biotype Th1 represents another example whereby members of one group are not genetically homogeneous. Whereas isolate 65 undoubtedly is a member of the T. harzianum biocontrol group, isolate 64 was consistently placed within the $T$. virens clade. RAPD and beta-tubulin gene sequence analyses have shown that all Th1

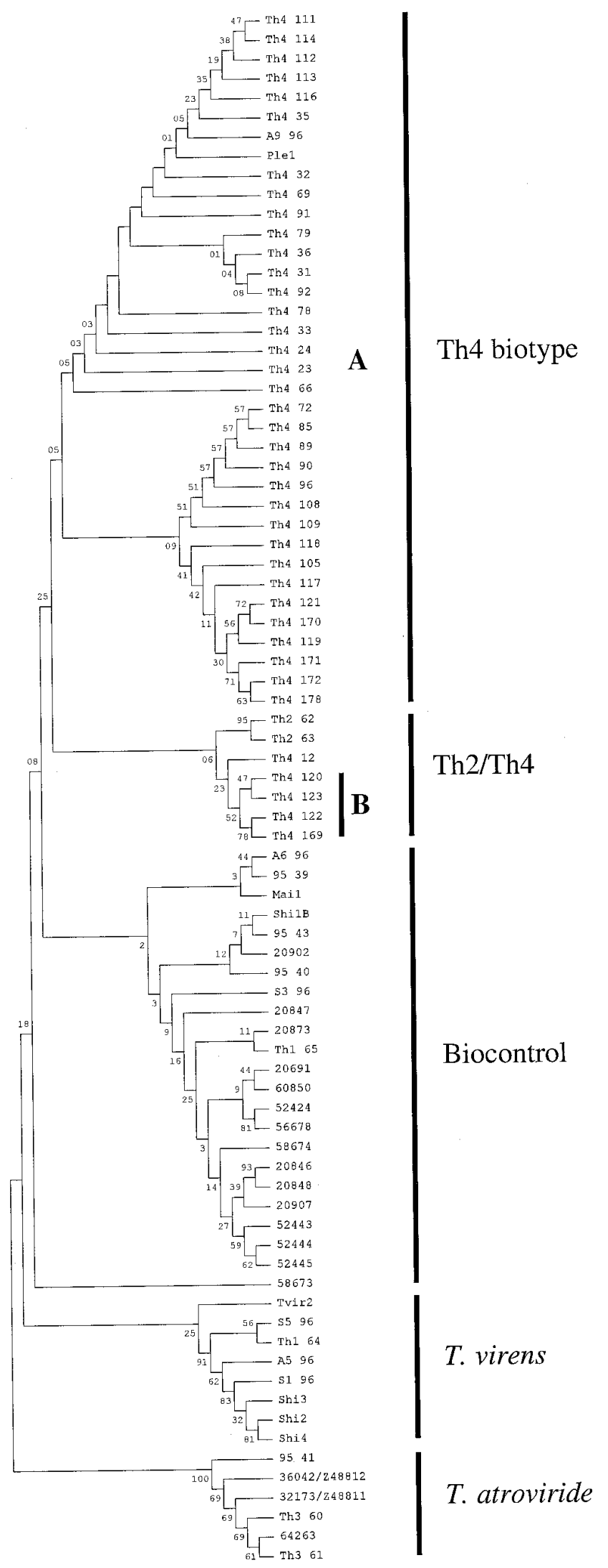

Vol. 89, No. 4, 1999 
isolates, with the exception of isolate 65 , are genetically uniform (X. Chen, C. P. Romaine, M. D. Ospina-Giraldo, and D. J. Royse, unpublished data). Therefore, it is possible that the true Th1 biotype is $T$. virens and not $T$. harzianum, as previously classified. Since only two isolates of the Th1 biotype were included in this analysis, however, it is not possible to determine with certainty whether the Th1 biotype is part of T. virens or T. harzianum.

Our results also suggest that two isolates used for biological control were misidentified. Phylogenetic analysis placed isolate ATCC 64263 (T. harzianum) as most closely related to biotype Th3 and ATCC strains 28036, 32173, and 36042, all identified as strains of $T$. atroviride. The independence of this group is supported by the highest bootstrap value (100\%) in our analyses (Fig. 2). Misidentification with members of these species may frequently occur because of the extreme similarity in their conidia (3). Likewise, bootstrap tests suggest that isolate 95-39, identified as T. inhamatum, is part of the T. harzianum group rather than constituting an independent lineage. Considering the wide range in sequence distribution of our samples, we propose that the consensus sequence found in this study be used as a reference sequence for further studies involving the identification and taxonomy of T. harzianum.

Most of the Th4 isolates appear to be very closely related to each other, confirming the results obtained by Qi et al. (21), who found very similar RAPD patterns in a population of Th4 isolates collected in Pennsylvania and Canada. Furthermore, all of these isolates were identified as Th2/Th4 biotypes using specific PCR primers (X. Chen, C. P. Romaine, M. D. Ospina-Giraldo, and D. J. Royse, unpublished data). The presence of several subgroups within the Th4 biotype (cluster A) suggests that some members of this biotype may have diverged along the evolutionary pathway (Fig. 2). In this group, it should be noted that the evolutionary rate is not constant for all isolates and several show an increased evolutionary distance. This suggestion is supported by bootstrap values as high as $72 \%$ (Fig. 2). Cluster B includes isolates 120, 122,123 , and 169, all of which came from different geographic locations. When compared with all isolates, this subgroup appears to be more closely related to the Th2 biotype, cause of green mold epidemics in Europe (Fig. 2). However, bootstrap values do not fully support this relationship (Fig. 2). In addition, DNA fingerprinting obtained by arbitrarily primed PCR indicated that isolates $120,122,123$, and 169 are similar to the Th4 biotype (data not shown). It would be helpful, therefore, to analyze other parts of these isolates' genome and additional Th2 isolates in order to further examine their genetic relatedness to Th2 and Th4.

Depending on the group analyzed, nucleotide variation within the ITS regions and the 5.8S rDNA appeared to occur in different locations. Hence, independent phylogenetic analyses were also conducted for Trichoderma spp., T. harzianum used as biocontrol agents, and Th4 biotype isolates. In any case, phylogenies obtained confirmed the internal topology and distribution observed when all samples were analyzed simultaneously (data not shown).

Multiple alignment algorithms, such as Clustal, rely on similar computational approaches. Initially, these methods align and score all sequence pairs in the data matrix. Subsequently, they evaluate and score all sequences until the final alignment is reached. This "progressive" approach utilizes the Needleman and Wunsch (19) pairwise algorithm iteratively to achieve the multiple alignment of a set of sequences. The essence of the progressive method, as developed by Feng and Doolittle $(9,10)$, is based on the rule "once a gap, always a gap." Therefore, the final alignment is usually dependent on the order of the pairwise alignments (9). To minimize this effect, a "clustering" alternative has been introduced in the method. First, the most closely related pair is determined. Subclusters that may exist in the set are revealed by the preliminary set of pairwise measurements. These subclusters are treated as units during the alignment process, without altering the relative positions of the nucleotides within the cluster. Thus, all subclusters are prealigned before the final alignment is performed (10).
This method is very accurate with closely related sequences (33). However, more recent versions of pairwise alignment-based algorithms, such as Clustal W, have introduced changes (mostly related to penalties due to gap number and location) that dramatically improved the sensitivity of the progressive alignment method for difficult alignments involving numerous or highly diverged sequences (33). Furthermore, Clustal W generates an output file in which the sequences are in the alignment order instead of maintaining the input file order. Finally, if unjustified gaps remain in the final alignment, they can be removed by manual editing. For these reasons, we selected Clustal $\mathrm{W}$ as the most appropriate algorithm for the multiple alignment of our highly complex data set (80 operational taxonomic units). In addition, the increased speed of distance methods allows more thorough testing of alternative tree topologies when large data sets are in use (32). Hard copies of the final sequence alignments are available upon request.

The selection of Clustal $\mathrm{W}$ for the multiple alignment was in accordance with the NJ method as the preferred choice for phylogenetic tree reconstruction. The NJ method does not assume a constant rate of nucleotide substitution (15) and, consequently, is more robust regarding the effects of unequal evolutionary rates in different lineages (33). Additional reasons supporting the use of the NJ method over other available methods are computational time and consistency when handling large data sets (15), as well as previous results from simulation studies (25). Furthermore, phylogenetic trees obtained by the NJ method can be tested with a statistically robust and very conservative standard error test (15).

In conclusion, we have found phylogenetic evidence suggesting that aggressive biotypes Th2 and Th4 are very closely related to biocontrol strains. However, the biocontrol strains do not appear to be responsible for the emergence of the green mold-causing biotypes of $T$. harzianum. Instead, Th2 and Th4 have evolved from a recent common ancestor for both biocontrol and green mold-related biotypes.

\section{LITERATURE CITED}

1. Agrios, G. 1997. Plant Pathology, 4th ed. Academic Press, San Diego, CA.

2. Bissett, J. 1991. A revision of the genus Trichoderma. II. Infrageneric classification. Can. J. Bot. 69:2357-2372.

3. Bissett, J. 1991. Trichoderma atroviride. Can. J. Bot. 70:639-641.

4. Brown, D., Wensink, P., and Jordan, E. 1972. A comparison of the ribosomal DNAs of Xenopus laevis and Xenopus mulleri: Evolution of tandem genes. J. Mol. Biol. 63:57-73.

5. Castle, A., Speranzini, D., Rghei, N., Alm, G., Rinker, D., and Bissett, J. 1998. Morphological and molecular identification of Trichoderma isolates on North America mushroom farms. Appl. Environ. Microbiol. 64:133-137.

6. Chet, I., Benhamou, N., and Haran, S. 1998. Mycoparasitism and lytic enzymes. Pages 153-172 in: Trichoderma and Gliocladium Vol. 2. Enzymes, Biological Control and Commercial Applications. G. E. Harman and C. P. Kubicek, eds. Taylor and Francis, London.

7. Doyle, O., Morris, E., and Clancy, K. 1991. Trichoderma green mouldUpdate. Irish Mushroom Rev. 3:13-17.

8. Felsenstein, J. 1985. Confidence limits on phylogenies: An approach using the bootstrap. Evolution 39:783-791.

9. Feng, D-F., and Doolittle, R. 1987. Progressive sequence alignment as a prerequisite to correct phylogenetic trees. J. Mol. Evol. 25:351-360.

10. Feng, D-F., and Doolittle, R. 1990. Progressive alignment and phylogenetic tree construction of protein sequences. Methods Enzymol. 183: 375-387.

11. Gams, W., and Bissett, J. 1998. Morphology and identification of Trichoderma. Pages 3-34 in: Trichoderma and Gliocladium Vol. 1. Basic Biology, Taxonomy and Genetics. C. P. Kubicek and G. E. Harman, eds. Taylor and Francis, London.

12. Jukes, T. H., and Cantor, C. R. 1969. Evolution of protein molecules. Pages 21-132 in: Mammalian Protein Metabolism. H. N. Munro, ed. Academic Press, New York.

13. Kuhls, K., Lieckfeldt, E., Samuels, G. J., Kovacs, W., Meyer, W., Petrini, O., Gams, W., Borner, T., and Kubicek, C. P. 1996. Molecular evidence that the asexual industrial fungus Trichoderma reesei is a clonal derivative of the ascomycete Hypocrea jecorina. Proc. Natl. Acad. Sci. U.S.A. 93:7755-7760. 
14. Lewin, B. 1997. Genes VI. Oxford University Press, New York.

15. Li, W-H. 1997. Molecular Evolution. Sinauer Associates, Sunderland, MA.

16. Lieckfeldt, E., Kuhls, K., and Muthumeenakshi, S. 1998. Molecular taxonomy of Trichoderma and Gliocladium and their teleomorphs. Pages 35-56 in: Trichoderma and Gliocladium Vol. 1. Basic Biology, Taxonomy and Genetics. C. P. Kubicek and G. E. Harman, eds. Taylor and Francis, London.

17. Morris, E., Doyle, O., and Clancy, K. J. 1995. A profile of Trichoderma species. I-Mushroom compost production. Mushroom Sci. 14:611-618.

18. Morris, E., Doyle, O., and Clancy, K. J. 1995. A profile of Trichoderma species. II-Mushroom growing units. Mushroom Sci. 14:619-625.

19. Needleman, S., and Wunsch, C. 1970. A general method applicable to the search of similarities in the amino acid sequence of two proteins. J. Mol. Biol. 48:443-453.

20. Ospina-Giraldo, M. D., Royse, D. J., Thon, M. R., Chen, X., and Romaine, C. P. 1998. Phylogenetic relationships of Trichoderma harzianum causing mushroom green mold in Europe and North America to other species of Trichoderma from world-wide sources. Mycologia 90:76-81.

21. Qi, T., Ospina-Giraldo, M. D., Romaine, C. P., Schlagnhaufer, B., Xi, C., Huff, D., and Royse, D. J. 1996. Genetic analysis of the Trichoderma spp. associated with the green mold epidemic in mushrooms. (Abstr.) Phytopathology 86:S89.

22. Rifai, M. A. 1969. A revision of the genus Trichoderma. Mycol. Pap. 116:1-56.

23. Rinker, D. L. 1994. Trichoderma green mold: A seminar by Dr. Donald Betterley, Monterey Labs. Mushroom News 42(4):28-32.

24. Romaine, C. P., Royse, D. J., Wuest, P. J., and Beyer, D. M. 1996. Mushroom green mold: Cause, edaphic factors and control. Mushroom News 44(11):20-23.

25. Saitou, N., and Imanishi, T. 1989. A theoretical study of the underesti- mation of branch lengths by the maximum parsimony principle. Syst. Zool. 38:1-6.

26. Saitou, N., and Nei, M. 1987. The neighbor-joining method: A new method for reconstructing phylogenetic trees. Mol. Biol. Evol. 4:406-425.

27. Seaby, D. A. 1987. Infection of mushroom compost by Trichoderma species. Mushroom J. 179:355-361.

28. Seaby, D. A. 1989. Further observations on Trichoderma. Mushroom J. 197:147-151.

29. Seaby, D. A. 1996. Differentiation of Trichoderma taxa associated with mushroom production. Plant Pathol. 45:905-912.

30. Seaby, D. A. 1996. Investigation of the epidemiology of green mould of mushroom (Agaricus bisporus) compost caused by Trichoderma harzianum. Plant Pathol. 45:913-923.

31. Seaby, D. 1998. Trichoderma as weed mould or pathogen in mushroom cultivation. Pages 267-287 in: Trichoderma and Gliocladium Vol. 2. Enzymes, Biological Control and Commercial Applications. G. E. Harman and C. P. Kubicek, eds. Taylor and Francis, London.

32. Swofford, D., Olsen, G., Waddell, P., and Hillis, D. 1996. Phylogenetic inference. Pages 407-514 in: Molecular Systematics. D. Hillis, C. Moritz, and B. Mable, eds. Sinauer Associates, Sunderland, MA.

33. Thompson, J., Higgins, D., and Gibson, T. 1994. CLUSTAL W: Improving the sensitivity of progressive multiple sequence alignment through sequence weighting, position-specific gap penalties and weight matrix choice. Nucleic Acid Res. 22:4673-4680.

34. Van Driesche, R., and Bellows, T. 1996. Biological Control. Chapman and Hall, New York.

35. White, T., Bruns, T., Lee, S., and Taylor, J. 1990. Amplification and direct sequencing of fungal ribosomal RNA genes for phylogenetics. Pages 315-322 in: PCR Protocols. M. Innis, D. Gelfand, J. Sninsky, and T. White, eds. Academic Press, San Diego, CA. 